\author{
A.R. Yeshkeyev, N.V. Popova* \\ E.A. Buketov Karaganda University, Karaganda \\ (E-mail: modth1705@mail.ru,dandn@mail.ru)
}

\title{
Small models of convex fragments of definable subsets
}

\begin{abstract}
This article discusses the problems of that part of Model Theory that studies the properties of countable models of inductive theories with additional properties, or, in other words, Jonsson theories. The characteristic features are analyzed on the basis of a review of works devoted to research in the field of the study of Jonsson theories and enough examples are given to conclude that the vast area of Jonsson theories is relevant to almost all branches of algebra. This article also discusses some combinations of Jonsson theories, presents the concepts of Jonsson theory, elementary theory, core Jonsson theories, as well as their combinations that admit a core model in the class of existentially closed models of this theory. The concepts of convexity, perfectness of theory semantic model, existentially closed model, algebraic primeness of model of the considered theory, as well as the criterion of perfection and the concept of rheostat are considered in this article. On the basis of the research carried out, the authors formulated and proved a theorem about the $\left(\nabla_{1}, \nabla_{2}\right)-c l$ coreness of the model for some perfect, convex, complete for existential sentences, existentially prime Jonsson theory $T$.
\end{abstract}

Keywords: Jonsson theory, Jonsson set, convex theory, fragment, existentially closed model.

We have studied the special countable models of inductive theories [1] with additional properties. These properties are the amalgamation property and the joint embedding property. In other such theories are called Jonsson theory [1]. The class of theory, which is determined by the conditions of Jonssonness, is quite wide. These include classical examples of theories as group theory, abelian group theory, field theory of fixed characteristic, theories of various kinds of rings, modules theory, and finally theory of polygons. The last example is essential for all problems of classical Model Theory by the results from work [2]. This paper shows that any complete theory is similar in some formal sense to the theory of polygons. As we can see from the above the areas of Jonsson theories a very wide and relates to almost all fields of algebra. Also, it should be noted that Jonsson theories are not complete, and therefore many classical problems from Model Theory and universal algebra considered for elementary theories of classes of algebras that are not complete are directly related to the study of Jonsson theories. In the study of Jonsson theories within the framework of this problem, the notion of a Jonsson spectrum and the notion of cosemanticness were defined, respectively. In connection with these new concepts, which respectively generalize the study of the problem of elementary equivalence of fixed classes of algebras in the framework of the study of Jonsson theories, results related to abelian groups and modules were obtained $[3,4]$. In connection with these new concepts, which respectively generalize the study of the problem of elementary equivalence of fixed classes. On the other hand, if we consider the class of models of an arbitrary Jonsson theory, then this class can be conditionally divided into two subclasses. The class of existentially closed models and the class of models that are not. It is well known that the elementarity of the subclass of existentially closed models is directly related to the perfection of the considered Jonsson theory [5]. Thus, the problems associated with the study of the behavior of a class of existentially closed models of an arbitrary or fixed Jonsson theory is an actual class of problems related to both the classical model theory and universal algebra.

Recently, quite a lot of works have been devoted to the study of Jonsson theories [6-9]. After the definition of Jonsson set [10], we noticed the usefulness of this concept in the sense that it made it

\footnotetext{
${ }^{*}$ Corresponding author.

E-mail: dandn@mail.ru
} 
possible to define the rheostat principle [11]. Among these works, one can single out the work related to definable subsets of the semantic model of the fixed Jonsson theory [11]. One of the new technical concepts is a fragment of a definable subset of the semantic model. As part of the study of this concept, the following works were considered [12-16].

Small models are usually understood as countable models of the considered theory. Since we will work with fragment models of some fixed Jonsson theory's models, generally speaking, it is not necessary that small fragment models coincide with small models of this theory. The concept of convexity of theory was introduced by A. Robinson [7; 41; Def. 2] and D. Kueker [17] studied the properties of core models for convex theories.

The main result of this article is Theorem $4 . \mathfrak{M}$ is a $\left(\nabla_{1}, \nabla_{2}\right)-c l$ core model for some perfect convex complete for existential sentences existentially prime Jonsson theory $T$ if and only if it is $\left(\nabla_{1}, \nabla_{2}\right)-c l$ core model $T^{*}$, where $T^{*}$ is the center of the theory $T$.

We give the following definitions and the related results, which we need for further work.

We begin with a classic definition of Jonsson theory and all the concepts needed to work with Jonsson theories.

Definition 1 [5]. A theory $T$ is called a Jonsson theory if:

1) the theory $T$ has infinite models;

2) the theory $T$ is inductive;

$3)$ the theory $T$ has the joint embedding property $(J E P)$;

4) the theory $T$ has the property of amalgam $(A P)$.

Definition 2 [5]. Let $\kappa \geq \omega$. Model $M$ of theory $T$ is called $\kappa$-universal for $T$, if each model $T$ with the power strictly less $\kappa$ isomorphically embedded in $M ; \kappa$-homogeneous for $T$, if for any two models $A$ and $A_{1}$ of theory $T$, which are submodels of $M$ with the power strictly less then $\kappa$ and for isomorphism $f: A \rightarrow A_{1}$ for each extension $B$ of model $A$, which is a submodel of $M$ and is model of $T$ with the power strictly less then $\kappa$ there exist the extension $B_{1}$ of model $A_{1}$, which is a submodel of $M$ and an isomorphism $g: B \rightarrow B_{1}$ which extends $f$.

Definition 3 [5]. A model $C$ of a Jonsson theory $T$ is called semantic model, if it is $\omega^{+}$-homogeneousuniversal.

Definition 4 [5]. The center of a Jonsson theory $T$ is an elementary theory $T^{*}$ of the semantic model $C$ of $T$, i.e. $T^{*}=T h(C)$.

Fact 1 [5]. Each Jonsson theory $T$ has $k^{+}$-homogeneous-universal model of power $2^{k}$. Conversely, if a theory $T$ is inductive and has an infinite model and $\omega^{+}$-homogeneous-universal model then the theory $T$ is a Jonsson theory.

Fact 2 [5]. Let $T$ is a Jonsson theory. Two $k$-homogeneous-universal models $M$ and $M_{1}$ of $T$ are elementary equivalents.

One of the main results obtained previously in the above definitions is the following result:

Theorem 1 (Criterion of perfectness) [5; 158]. Let $T$ be a Jonsson theory. Then the following conditions are equivalent:

1) Theory $T$ is perfect;

2) Theory $T^{*}$ is a model companion of theory $T$.

Since there are much fewer perfect theories than imperfect ones, and only the perfectness of Jonsson theory guarantees the elementary class of existentially closed models of this theory, the study of properties of the class of existentially closed models is a very important task. Recall the classic definition of an existentially closed model for any theory.

Definition 5. A model $A$ of theory $T$ is called existentially closed if for any model $B$ and any existential formula $\varphi(\bar{x})$ with constants of $A$ we have $A \models \exists \bar{x} \varphi(\bar{x})$ provided that $A$ is a submodel of $B$ and $B \models \exists \bar{x} \varphi(\bar{x})$.

We denote by $E_{T}$ the class of all existentially closed models of the theory $T$. 
The existence of an existentially closed model is not necessary for any theory. But, as is well known from the following theorem [1], for any inductive theory $T E_{T}$ is non-empty.

Theorem 2 [1; 97; Proposition 8.12]. If the theory $T$ is inductive, then any model of the theory $T$ is embedded in an existentially closed model of the theory $T$.

The next aspect related to the models of the theory is called the convexity of theory. The concept of convexity of theory was first introduced by the well-known specialist in the field of Model Theory A. Robinson.

Definition 6 [7]. A theory $T$ is called convex if for any its model $A$ and any family $\left\{B_{i} \mid i \in I\right\}$ of substructures of $A$, which are models of the theory $T$, the intersection $\bigcap_{i \in I} B_{i}$ is a model of $T$, provided it is non-empty. If besides such an intersection is never empty, then $T$ is called strongly convex.

As a simple example of a convex but not strongly convex theory, we can give the following example: consider a theory $T$ that defines an equivalence relation. It is clear that any substructure of the model $T$ also satisfies the axioms of $T$, but the intersection of two substructures may well turn out to be empty. An example of a strongly convex theory is group theory. A simple example of a nonconvex theory is given by the following example: the theory of densely ordered sets with different end elements. On the other hand, if the language of a theory $T$ contains at least one constant $a$ and the theory $T$ is convex, then it is also strongly convex since any model from ModT contains an element that realizes this constant $a$.

The concept of an algebraically prime model was also introduced by A. Robinson. This concept is a generalization of the concept of a prime model, which says that the model is prime if and only if, it is elementary embeddable in any model of the considered theory. A model is called algebraically prime if and only if, it is isomorphically embedded in any model of the considered theory. Since in the definition of Jonsson theory we see only isomorphic embeddings, it is naturally important for us to know the behavior of an algebraically prime model. If in the case of a prime model we have a good criterion in the form of R. Vaught's theorem: a model is prime if and only if it is countable and atomic. In the case of algebraic primeness there is no such criterion. Therefore, the study of algebraically prime models is an important task in the study of Jonsson theory.

Definition \%. Model $A$ of theory $T$ is called core if it is isomorphically embedded in any model of a given theory and this isomorphism exactly one.

As part of the study of inductive theories, we define the core theory [11].

Definition 8. An inductive theory $T$ is called a core theory if there exists a model $A \in E_{T}$ such that for any model $B \in E_{T}$ there exists a unique isomorphism from $A$ to $B$.

Definition 9. The inductive theory $T$ is called the existentially prime if:

1 ) it has an algebraically prime model, the class of its $A P$ (algebraically prime models) denote by $A P_{T}$

2) class $E_{T}$ nontrivial intersects with class $A P_{T}$, i.e. $A P_{T} \cap E_{T} \neq 0$.

When studying Jonsson theories, we noticed that not all of them have an algebraically prime model. But there are also such Jonsson theories that have such a model. Therefore, it was natural to define the following subclasses of inductive theories.

The following definition makes sense in the case of imperfect Jonsson theories. In the perfect case, the concept of algebraic primeness is considered in the class of the considered theory's models. Since in the perfect case will be $M o d T^{*}=E_{T}$.

Definition 10 [11]. Theory $T$ is called existentially algebraically prime $(E A P)$ if it has a model $A \in E_{T}$ such that for any $B \in E_{T}, A$ is isomorphically embedded in $B$.

In the modern Model Theory, the definable subsets of the considered models play an important role. A set is called definable if there is a formula of the language, the solution of which is the given set. We distinguish such special definable subsets of the semantic model of the considered Jonsson theory through the following definition. 
Definition 11. Let $X \subseteq C$. We will say that a set $X$ is $\nabla-c l$-Jonsson subset of $C$ if $X$ satisfies the following conditions:

1) $X$ is $\nabla$-definable set (this means that there is a formula from $\nabla$, the solution of which in the $C$ is the set $X$, where $\nabla \subseteq L$, that is $\nabla$ is a view of formula, for example $\exists, \forall, \forall \exists$ and so on.);

2) $\operatorname{cl}(X)=M, M \in E_{T}$, where $c l$ is some closure operator defining a pregeometry [16] over $C$ (for example $c l=a c l$ or $c l=d c l$ ).

In order to take advantage of the rheostat principle, which will be applied to a specific model, we must define a series of definable subsets, in which the foundations of a rheostat are laid in the form of a formula subset with additional conditions regarding primeness atomicity, coreness, and existentially closeness, when necessary.

Definition 12 [11]. A set $A$ is said to be $\left(\nabla_{1}, \nabla_{2}\right)-c l$ atomic in the theory $T$, if

1) $\forall a \in A, \exists \varphi \in \nabla_{1}$ such that for any formula $\psi \in \nabla_{2}$ follows that $\varphi$ is a complete formula for $\psi$ and $C \models \varphi(a)$;

2) $\operatorname{cl}(A)=M, M \in E_{T}$,

and obtained model $M$ is said to be $\left(\nabla_{1}, \nabla_{2}\right)-c l$ atomic model of theory $T$.

Definition 13 [11]. A set $A$ is said to be weakly $\left(\nabla_{1}, \nabla_{2}\right)-c l$ is atomic in $T$, if

1) $\forall a \in A, \exists \varphi \in \nabla_{1}$ such that in $C \models \varphi(a)$ for any formula $\psi \in \nabla_{2}$ follow that $T \models(\varphi \rightarrow \psi)$ whenever $\psi(x)$ of $\nabla_{2}$ and $C=\psi(a)$;

2) $\operatorname{cl}(A)=M, M \in E_{T}$,

and obtained model $M$ is said to be weakly $\left(\nabla_{1}, \nabla_{2}\right)-c l$ atomic model of theory $T$.

Definition 14 [11]. A set $A$ is said to be $\left(\nabla_{1}, \nabla_{2}\right)-c l$-algebraically prime in the theory $T$, if

1) If $A$ is $\left(\nabla_{1}, \nabla_{2}\right)-c l$-atomic set in $T$;

2) $\operatorname{cl}(A)=M, M \in A P_{T}$,

and obtained model $M$ is said to be $\left(\nabla_{1}, \nabla_{2}\right)-c l$ algebraically prime model of theory $T$.

Definition 15 [11]. The set $A$ is said to be $\left(\nabla_{1}, \nabla_{2}\right)-c l$-core in the theory $T$, if

1) $A$ is $\left(\nabla_{1}, \nabla_{2}\right)$ a $c l$ - atomic set in the theory $T$;

2) $\operatorname{cl}(A)=M$, where $M$ is the core model of theory $T$

and obtained model $M$ is said to be $\left(\nabla_{1}, \nabla_{2}\right)-c l$ core model of theory $T$.

Theorem 3 [17; Th. 2.1] For any $T$ the following conditions are equivalent:

1) $\mathfrak{C}$ is a core structure for $T$.

2) $\mathfrak{C}$ is a model of every universal sentence consistent with $T$, and there are existential formulas $\varphi_{i}(x)$ and $k_{i} \in \omega$, for $i \in I$, such that

$$
\mathfrak{C}, T \models \exists^{=k_{i}} x \varphi_{i} \text { for all } i \in I,
$$

and

$$
\mathfrak{C} \models \forall x \bigvee_{i \in I} \varphi_{i}
$$

The following two definitions (Def. 16 and Def. 17) will have a value for the formulation of further results of this article.

Definition 16. Let $T_{1}$ and $T_{2}$ are an arbitrary Jonsson theories. We say, that $T_{1}$ and $T_{2}$ are the $h$-syntactically similar, where $h$ is map $h: E\left(T_{1}\right) \longrightarrow E\left(T_{2}\right)$ such that

1) restriction $h$ to $E_{n}\left(T_{1}\right)$ is homomorphism of lattices $E_{n}\left(T_{1}\right)$ and $E_{n}\left(T_{2}\right), n<\omega$;

2) $h\left(\exists v_{n+1} \varphi\right)=\exists v_{n+1} h(\varphi), \varphi \in E_{n+1}(T), n<\omega$;

3) $h\left(v_{1}=v_{2}\right)=\left(v_{1}=v_{2}\right)$.

The following definition belongs to the first author and is a measure of the change in the rheostat principle for Jonsson theories.

Definition 17. Let $T$ be some Jonsson theory, $C$ a semantic model of the theory $T, X \subseteq C, X$ a theoretical set. $\varphi(C)=X, \varphi(x) \in L$. 
If the universal closure $\varphi(x)$ is a Jonsson theory and the Kaiser hull $M^{0}=T h_{\forall \exists}(M), M \in E_{T}$, where $M=\operatorname{cl}(\varphi(C))$, then we will say that $\varphi(x)$ is a rheostat if there is an $h$-syntactic similarity between the theories $T$ and $T h_{\forall \exists}(M)$.

The next result connects the convexity of the theory and its center in connection with the existence of the above form of the core of the model (Def. 15).

Symbols $\nabla_{1}, \nabla_{2}, c l$ s in definitions 11-16.

Further, by the requirements for the content of Theorem 4: let $\nabla_{1}=\{\varphi(x)\}, \nabla_{2}=\{\varphi(x)\}$, $c l=a c l, c l=d c l, \varphi(x)$ there is a rheostat such that $c l(X)=M, M^{0}=T h_{\forall \exists}(M), \theta=\forall x \exists \bar{y} \psi(x, \bar{y}), \theta$ there is Jonsson theory, $\varphi(x)=\exists \bar{y} \psi(x, \bar{y})$ and $h: E(\theta) \rightarrow M^{0}$, satisfying the definition 16 .

Let $\operatorname{Ker} h$ be trivial, i.e. consists only of identical congruence.

Theorem 4. $\mathfrak{M}$ is $\left(\nabla_{1}, \nabla_{2}\right)-c l$ a core model for some perfect, convex, complete for existential sentences, existentially prime Jonsson theory $T$ if and only if it is a $\left(\nabla_{1}, \nabla_{2}\right)-c l$ core model $T^{*}$, where $T^{*}$ is the center of $T$.

Proof. Let's prove the sufficiency. Suppose that $T^{*}$ is strongly convex and $\mathfrak{M}$ is the $\left(\nabla_{1}, \nabla_{2}\right)-c l$ core model $T^{*}$. Let $C$ be a semantic model of $T$. Let $\mathfrak{A}$ be any model of $T$ and $\mathfrak{A}_{0}$ be a sufficiently saturated existentially closed extension of $\mathfrak{A}$. Then $\mathfrak{M} \exists \mathfrak{A}_{\mathfrak{o}}$, which means that any $\exists$-sentence true in $\mathfrak{M}$ implies being true in $\mathfrak{A}_{\mathfrak{o}}$. This is true since any model of the theory $T$ can be isomorphically embedded in $C$, in particular, the models $\mathfrak{A}_{\mathfrak{o}}, \mathfrak{A}_{\mathfrak{o}}$ are also embedded in $C$ since the theory $T$ is perfect, the model $\mathfrak{A}_{\mathfrak{o}}$. And due to the strong convexity of the theory $T^{*}$ the model $\mathfrak{M}$ is isomorphically embedded in the model $\mathfrak{A}_{\mathfrak{o}}$. Therefore, $\mathfrak{M} \cong \mathfrak{M}_{1}$, for some $\mathfrak{M}_{1} \subseteq \mathfrak{A}_{\mathfrak{o}}$. Since no proper submodel of $\mathfrak{M}$ is a model of $T^{*}$, we must have

$$
\mathfrak{M}_{1}=\cap\left\{\mathfrak{B}: \mathfrak{B} \subseteq \mathfrak{A}_{\mathfrak{o}} \text { and } \mathfrak{B}=T\right\}
$$

In particular $\mathfrak{M}_{1} \subseteq \mathfrak{A}$. If $\mathfrak{M}$ is isomorphic to some other $\mathfrak{M}_{2} \subseteq \mathfrak{A}$, then the same argument shows that $\mathfrak{M}_{1}=\mathfrak{M}_{2}$. Therefore, $\mathfrak{M}$ is $\left(\nabla_{1}, \nabla_{2}\right)-c l$ core model for $T$.

Let's prove the necessity. Let $\mathfrak{M}-\left(\nabla_{1}, \nabla_{2}\right)-c l$ core model for $T$, and let $T^{*}$ be the center of the theory $T$, then it is obvious that the set of all existential and universal sentences is true in $\mathfrak{M}$, since $T^{*}=T h(C)$. Condition $(2)$ of Theorem $2.1[17 ; 157]$ holds for $\mathfrak{M}$ and $T^{*}$ so that $\mathfrak{M}$ is $\left(\nabla_{1}, \nabla_{2}\right)-c l$ core model for $T^{*}$. Let $\mathfrak{A}$ any model $T^{*} . \mathfrak{M}$ is isomorphic to exactly one $\mathfrak{M}^{\prime} \subseteq \mathfrak{A}$ and can also be embedded in any other model $T^{*}$, therefore,

$$
\mathfrak{M}^{\prime}=\cap\left\{\mathfrak{B}: \mathfrak{B} \subseteq \mathfrak{A} \text { and } \mathfrak{B}=T^{*}\right\}
$$

It follows that $T^{*}$ is strongly convex and that $\mathfrak{M}$ is $\left(\nabla_{1}, \nabla_{2}\right)-c l$ core model $T^{*}$, as clamed.

\section{References}

1 Barwise J.Ed. Handbook of mathematical logic. Part 1, Model Theory / J. Barwise // Science. - M., 1982.

2 Mustafin T.G. On similarities of complete theories / T.G. Mustafin // Logic Colloquium '90. Proceedings of the Annual European Summer Meeting of the Association for Symbolic Logic. Helsinki, 1990. - P. 259-265.

3 Ешкеев А.Р. $J S p$-косемантичность и $J S B$-свойство абелевых групп [Электронный ресурс] / A.P. Ешкеев, О.И. Ульбрихт // Siberian Electronic Mathematical Reports. - Режим доступа: http://semr.math.nsc.ru. Вып. 13(2016). - C. 861-874. DOI: 10.17377/semi.2016.13.068

4 Ешкеев A.P. $J S p$-косемантичность $R$ модулей [Электронный ресурс] / A.P. Ешкеев, О.И. Ульбрихт // Siberian electronics mathematical reports. - Режим доступа: http://semr. math.nsc.ru. - Вып. 16(2019). - C. 1233-1244. DOI: 10.33048/semi.2019.16.084

5 Ешкеев А.Р. Йонсоновские теории и их классы моделей: моногр. / А.Р. Ешкеев, М.Т. Касыметова. - Караганда: Изд-во КарГУ, 2016. - 370 с. 
6 Yeshkeyev A.R. On lattice of existential formulas for fragment of Jonsson set / A.R. Yeshkeyev, O.I. Ulbrikht // Bulletin of the Karaganda University - Mathematics. - 2015. - Vol. 79. No. 3. - P. 33-39.

7 Yeshkeyev A.R. Companions of the fragments in the Jonsson enrichment / A.R. Yeshkeyev // Bulletin of the Karaganda University - Mathematics. - 2017. - Vol. 85. - No. 1. - P. 41-45. DOI: $10.31489 / 2017 \mathrm{M} 1 / 41-45$

8 Yeshkeyev A.R. The Properties of Similarity for Jonsson's Theories and Their Models / A.R. Yeshkeyev // Bulletin of the Karaganda University - Mathematics. - 2015. - Vol. 80. No. 4. - P. 52-59.

9 Yeshkeyev A.R. del-cl-atomic and prime sets / A.R. Yeshkeyev, A.K. Issayeva // Bulletin of the Karaganda University - Mathematics. - 2019. - Vol. 93. - No. 1. - P. 88-94. DOI: $10.31489 / 2019 \mathrm{M} 1 / 88-94$

10 Yeshkeyev A.R. Strongly minimal Jonsson sets and their properties / A.R. Yeshkeyev // Bulletin of the Karaganda University - Mathematics. - 2015. - Vol. 80. - No. 4. - P. 47-51.

11 Yeshkeyev A.R. The atomic definable subsets of semantic model / A.R. Yeshkeyev, N.M. Mussina, A.K. Issayeva // Bulletin of the Karaganda University - Mathematics. - 2019. - Vol. 94. - No. 2. - P. 84-91. DOI 10.31489/2019M2/84-91

12 Yeshkeyev A.R. The properties of central types with respect to enrichment by Jonsson set / A.R. Yeshkeyev // Bulletin of the Karaganda University - Mathematics. - 2017. - Vol. 85. No. 1. - P. 36-40. DOI: 10.31489/2017M1/36-40

13 Yeshkeyev A.R. The structure of lattices of positive existential formulae of (Delta - PJ)-theories / A.R. Yeshkeyev // ScienceAsia. - 2013. - Vol. 39. - No. 1. - P. 19-24.

14 Yeshkeyev A.R. Properties of hybrids of Jonsson theories / A.R. Yeshkeyev, N. M. Mussina // Bulletin of the Karaganda University - Mathematics. - 2018. - Vol. 92. - No. 4. - P. 99-104. DOI: $10.31489 / 2018 \mathrm{M} 4 / 99-104$

15 Yeshkeyev A.R. Model-theoretical questions of the Jonsson spectrum / A.R. Yeshkeyev // Bulletin of the Karaganda University - Mathematics. -2020. - Vol. 98. - No. 2. - P. 165-173. DOI: $10.31489 / 2020 \mathrm{M} 2 / 165-173$

16 Yeshkeyev A.R. The $J$-minimal sets in the hereditary theories / A.R. Yeshkeyev, M.T. Omarova, G.E. Zhumabekova // Bulletin of the Karaganda University - Mathematics. - 2019. - Vol. 94. - No. 2. - P. 92-98. DOI 10.31489/2019M2/92-98

17 Kueker D.W. Core structures for theories / D.W. Kueker // Fundamenta Mathematicae LXXXIX (1973). - P. $154-171$.

\author{
А.Р. Ешкеев, Н.В. Попова
}

\title{
Анықталған ішкі жиындардың дөңес фрагменттерінің кішігірім модельдерінің типтері
}

\footnotetext{
Мақалада модельдер теориясының қосымша қасиеттері бар индуктивті теориялардың саналымды модельдерінің қасиеттерін зерттейтін бөлігінің, немесе, басқаша айтқанда, йонсондық теориялардың, мәселелері қарастырылды. Йонсондық теорияды зерттеу аясында анықтауға арналған жұмыстарға шолу негізінде сипаттамалық ерекшеліктер талданды және йонсондық теориялардың кең аумағы алгебраның барлық дерлік салаларына қатысты деген тұжырым жасауға жеткілікті мысалдар келтірілген. Сонымен қатар авторлар йонсондық теориялардың кейбір комбинацияларын талқылап, йонсондық теорияның, элементарлық теорияның, ядролық йонсондық теорияның ұғымдарын, сондай-ақ осы теорияның экзистенциалды тұйық модельдері класында ядролық модельді рұқсат ететін олардың комбинацияларын келтірген. Мақалада дөңестілік, теорияның кемелділігі, семантикалық модель,
} 
экзистенциалды тұйық модель, қарастырылатын теорияның алгебралық жай моделі, сондай-ақ кемелдік критерийі және реостат ұғымы қарастырылған. Зерттеу негізінде авторлар экзистенциалды сөйлемдер үшін толық, дөңес, экзистенциалды жай йонсондық теория $T$ үшін модельдің $\left(\nabla_{1}, \nabla_{2}\right)-c l$ ядролылығы туралы теореманы тұжырымдады және дәлелдеді.

Kiлm сөздер: йонсондық теория, йонсондық спектр, йонсондық жиын, теоретикалық жиын, фрагмент.

\author{
А.Р. Ешкеев, Н.В. Попова
}

\title{
Малые модели выпуклых фрагментов определимых подмножеств
}

\begin{abstract}
В статье рассмотрены проблемы той части теории моделей, которая изучает свойства счетных моделей индуктивных теорий с дополнительными свойствами, или, иначе говоря, йонсоновские теории. Проанализированы характерные особенности, на основании обзора работ, посвященных исследованиям в области изучения йонсоновских теорий, и приведено достаточно примеров, позволяющих сделать вывод, что обширный ареал йонсоновских теорий имеет отношение практически ко всем разделам алгебры. Авторами обсуждены некоторые комбинации йонсоновских теорий, приведены понятия йонсоновской теории, элементарной теории, ядерной йонсоновской теории, а также их комбинаций, допускающих ядерную модель в классе экзистенциально замкнутых моделей этой теории. Кроме того, в статье понятия выпуклости, совершенства теории, семантической модели, экзистенциально замкнутой модели, алгебраической простоты модели рассматриваемой теории, а также критерий совершенности и понятие реостата всесторонне изучены. На основе проведенного исследования авторами сформулирована и доказана теорема о $\left(\nabla_{1}, \nabla_{2}\right)-c l$ ядерности модели для некоторой совершенной, выпуклой, полной для экзистенциальных предложений, экзистенциально простой йонсоновской теории $T$.
\end{abstract}

Ключевые слова: йонсоновская теория, йононовский спектр, йонсоновское множество, теоретическое множество, фрагмент.

\section{References}

1 Barwise, J. (1982). Ed. Handbook of mathematical logic. Part 1, Model Theory. Science, Moscow.

2 Mustafin, T.G. (1990). On similarities of complete theories. Logic Colloquium '90. Proceedings of the Annual European Summer Meeting of the Association for Symbolic Logic. Helsinki.

3 Yeshkeyev, A.R. \& Ulbrikht, O.I. (2016). JSp-kosemantichnost i JSB-svoistvo abelevykh hrupp [JSp-cosemanticness and JSB property of Abelian groups]. Siberian Electronic Mathematical Reports. Retrieved from http://semr.math.nsc.ru. DOI: 10.17377/semi.2016.13.068 [in Russian].

4 Yeshkeyev, A.R. \& Ulbrikht, O.I. (2019). JSp-kosemantichnost R-modulei /JSp-cosemanticness of R-modules]. Siberian Electronic Mathematical Reports [Jelektronnyj resurs]. Retrieved from http://semr.math.nsc.ru. DOI: 10.33048/semi.2019.16.084 [in Russian].

5 Yeshkeyev, A.R. \& Kassymetova, M.T. (2016). Yonsonovskie teorii i ikh klassy modelei /Jonsson theories and their classes of models]. Karaganda: Izdatelstvo KarHU [in Russian].

6 Yeshkeyev, A.R. \& Ulbrikht, O.I. (2015). On lattice of existential formulas for fragment of Jonsson set. Bulletin of the Karaganda University - Mathematics, Vol. 79, 3, 33-39.

7 Yeshkeyev, A.R. (2017). Companions of the fragments in the Jonsson enrichment. Bulletin of the Karaganda University - Mathematics, Vol. 85, 1, 41-45. DOI: 10.31489/2017M1/41-45

8 Yeshkeyev, A.R. (2015). The Properties of Similarity for Jonsson's Theories and Their Models. Bulletin of the Karaganda University - Mathematics, Vol. 80, 4, 52-59.

9 Yeshkeyev, A.R. \& Issayeva, A.K. (2019). del-cl-atomic and prime sets. Bulletin of the Karaganda University - Mathematics, Vol. 93, 1, 88-94. DOI: 10.31489/2019M1/88-94 
10 Yeshkeyev, A.R. (2015). Strongly minimal Jonsson sets and their properties. Bulletin of the Karaganda University - Mathematics, Vol. 80, 4, 47-51.

11 Yeshkeyev, A.R., Issayeva, A.K., \& Mussina, N.M. (2019). The atomic definable subsets of semantic model. Bulletin of the Karaganda University - Mathematics, Vol. 94, 2, 84-91. DOI 10.31489/2019M2/84-91

12 Yeshkeyev, A.R. (2017). The properties of central types with respect to enrichment by Jonsson set. Bulletin of the Karaganda University - Mathematics, Vol. 85, 1, 36-40. DOI: 10.31489/2017M1/3640

13 Yeshkeye, A.R. (2013). The structure of lattices of positive existential formulae of (Delta - PJ)theories ScienceAsia, Vol. 39, 1, 19-24.

14 Yeshkeyev, A.R., \& Mussina, N.M. (2018). Properties of hybrids of Jonsson theories. Bulletin of the Karaganda University - Mathematics, Vol. 92, 4, 99-104. DOI: 10.31489/2018M4/99-104

15 Yeshkeyev, A.R. (2020). Model-theoretical questions of the Jonsson spectrum Bulletin of the Karaganda University - Mathematics, Vol. 98, 2, 165-173. DOI: 10.31489/2020M2/165-173

16 Yeshkeyev, A.R., Omarova, M.T., \& Zhumabekova G.E. (2019). The J-minimal sets in the hereditary theories. Bulletin of the Karaganda University - Mathematics, Vol. 94, 2, 92-98. DOI 10.31489/2019M2/92-98

17 Kueker, D.W. (1973). Core structures for theories. Fundamenta Mathematicae LXXXIX, pp. 154171 